\title{
8. Sınıf Öğrencilerinin Temel Eğitimden Orta Öğretime Geçiş (TEOG) Sınavına İlişkin Algılarının Metaforlar Aracılığılyla İncelenmesi
}

\author{
Doç. Dr. Nil DUBAN* \\ Afyon Kocatepe Üniversitesi, Eğitim Fakültesi, Afyonkarahisar / Türkiye \\ Harun ARISOY \\ Afyon Kocatepe Üniversitesi, Eğitim Fakültesi, Afyonkarahisar / Türkiye
}

\section{$\ddot{\mathbf{O z}}$}

8. sınıfta yapılan TEOG sınavı, Türk Millî Eğitim Sistemi'nde birçok öğrencinin akademik yaşamına nasıl devam edeceğini belirleyen ve öğrencilerin hayatlarında önemli bir yere sâhip olan ilk karşılaşıkları merkezî sınavdır. Öğrencilerin TEOG sınavını ne şekilde algıladıkları hem kaygı durumlarını hem de motivasyon düzeylerini ortaya koymada ve etkili biçimde rehberlik hizmetlerini yürütmede önemli bir veri kaynağıdır. Bu araştırmanın temel amacı 8. sınıf öğrencilerinin TEOG sınavına yönelik algılarının metaforlar aracılı̆̆ıyla incelenmesidir. Araştırmada, nitel araştırma yöntemlerinden olgu bilim deseni kullanılmıştır. Araştırmanın katılımcılarını 2015-2016 eğitim-öğretim yılında Afyonkarahisar il merkezi, ilçeleri ve köylerinde yer alan sekiz devlet ortaokulunun 8. sınıfina devam etmekte olan 267 öğrenci oluş-

* Sorumlu Yazar. Tel: +902722281418Ｅ-posta:nduban@gmail.comＯRCID: 0000-0002-8851-0114

(C) 2017 Kalem Eğitim ve Sağlık Hizmetleri Vakfı. Bütün Hakları Saklıdır. ISSN: 2146-5606 
turmaktadır. Araştırmada veri toplama aracı olarak öğrencilerin TEOG sınavına yönelik metaforlarını belirleme aracı kullanılmıştır. Toplanan veriler içerik analiz tekniği ile analiz edilip yorumlanmıştır. Altı farklı kategoride toplam 240 geçerli metafor geliştirilmiştir. Bu kategoriler zorlanma, önem, hedef, beklenti, emek, memnuniyet şeklindedir. Öğrencilerin metaforlarının gerekçelerine ilişkin olarak yazdıkları cümlelerden yapılan doğrudan alıntılar ile bulgular desteklenmiştir. Araştırma sonucunda il ve ilçe merkezinde eğitim gören öğrencilerin genel olarak TEOG sınavı nedeniyle stres, kaygı ve korku yaşadıkları ortaya çıkmıştır. Köy ve kasabada eğitim gören öğrenciler için ise TEOG sınavının önemli olduğu ve ortaöğretim kurumlarında daha iyi bir eğitim görme ve iyi bir gelecek sağlama adına bir araç veya aşama olarak görüldüğü sonucuna ulaşılmıştır.

Anahtar Kelimeler: TEOG; Metafor; 8. sınıf öğrencileri; Genel sınavlar.

\title{
Analysing the Perceptions of $8^{\text {th }}$ Graders on \\ Examination for the Transition from Secondary to High School Education (TEOG) Through Metaphors
}

\begin{abstract}
TEOG is a central examination administered to $8^{\text {th }}$ graders in Turkey. The primary purpose of this study was to analyze the perceptions of $8^{\text {th }}$ graders on TEOG exam through metaphors. This qualitative study was designed based on phenomenological approach. The study group was comprised of $267,8^{\text {th }}$ graders enrolled at the state schools of Afyonkarahisar city center, towns and villages. In the current study, the content analysis was conducted to analyze the data. Following the exclusion process, the metaphor analyses resulted in six categories within the scope of the study. These categories were as follows: endeavor, challenges, expectations, significance, objective, and satisfaction. The students used the most of the metaphors in the category of challenges. These results indicated that TEOG exam creates stress and fear for the secondary school students, and the students have anxiety due to TEOG exam. The metaphors of the students in villages differ from the students in towns and city centers.
\end{abstract}

Keywords: TEOG; Metaphors; $8^{\text {th }}$ graders; Central examinations. 


\section{Extended Summary}

\section{Purpose}

TEOG is a central examination administered to $8^{\text {th }}$ graders in Turkey. It might also be regarded as a milestone for many students in the National Education System of Turkey as a determinant of their further school life. The perceptions of students on TEOG exam provide reliable data in order to reveal both the state of anxiety and the motivation levels, which in turn help to offer counselling services effectively. The primary purpose of this study was to analyze the perceptions of $8^{\text {th }}$ graders on TEOG exam through metaphors.

\section{Method}

This qualitative study was designed based on phenomenological approach. The maximum variation sampling, an example of the purposeful sampling strategies, was adopted to select the participants of the current study. This study group was comprised of $267,8^{\text {th }}$ graders enrolled at the state schools of Afyonkarahisar city center, towns and villages. Eighty three of the students were studying in the city center, 94 in towns and 90 in villages. In the current study, the content analysis was conducted to analyze the data. The analysis of the data consisted of three phases. First, the metaphors spelled by pre-service teachers were tabulated in relation to their sources. Then, the relationship between the subject of the metaphor and its source was elaborated. Some papers had no source of the metaphor, and some metaphors were not justified by the participants. Therefore, this kind of metaphors were sorted out and excluded. As a result of this exclusion, 27 papers were labelled as unclassified, and the content analysis proceeded with 240 papers for the categorization. Following the exclusion process, the metaphor analyses resulted in six categories within the scope of the study.

\section{Results}

The categories of the research were as follows: endeavor, challenges, expectations, significance, objective, and satisfaction. The students used the most of the metaphors in the category of challenges (27.92\%). These results indicated that TEOG exam creates stress and fear for the secondary school students, and the students have exam anxiety due to TEOG exam. The metaphors of the students in villages differ from the students in towns and city centers. 


\section{Discussion and Conclusion}

The students in villages told metaphors on TEOG exam for significance (33.33\%) and objective (30.95\%) categories. In other words, TEOG exam is very important for the students in villages, and they consider the exam a tool or a phase to get a better education or to establish a better future. The students in towns told metaphors on TEOG exam for challenges (31.25\%) and objective $(27.50 \%)$ categories. The results can be interpreted that the students in towns have stress, fear and exam anxiety. Furthermore, TEOG exam is a tool for a better high school, namely a better future for them. The students in city centers literalized metaphors on TEOG exam for challenges $(30.26 \%)$ and expectations $(27.63 \%)$. They have stress and exam anxiety due to TEOG exam; however, the metaphors indicate the expectations regarding the exam. As another result, the students in villages have less stress, fear and exam anxiety than their counterparts in towns and city centers do.

\section{Giriş}

Her ülkenin ihtiyaç duyduğu ve istediği insan tipinin yetiştirilmesi ancak eğitim ile gerçekleştirilebilmektedir. Eğitim bir ülkenin her alanında etkilidir. Özellikle, ülkelerin ekonomisinden toplumsal yaşantısına kadar neredeyse her alanda bu etki görülebilmektedir (Çepni ve Çil, 2010, s.2).

Eğitim bir süreçtir. Bu süreç; eğitim amaçları, eğitim ve öğretim uygulamaları ile ölçme ve değerlendirme olmak üzere birbirleriyle sürekli ve karş11klı etkileşim içinde olan dinamik bir yapıya sâhiptir. Eğitim sürecini oluşturan ögeler ise, eğitim ve öğretim amaçları, öğrencilerde ulaşılması istenen davranış değişikliklerini; eğitim ve öğretim uygulamaları, öğrencilerin ulaşması istenen davranış değişiklerinin sağlanmasında kullanılan yöntemleri, teknikleri, araçları ve diğer hususları; ölçme ve değerlendirme, eğitim ve ögretim uygulamaları ile eğitim amaçlarında belirlenen davranış değişikliklerinin ne ölçüde gerçekleştirildiğini belirlemektedir (Koç, 2007).

Bireyin davranışlarında kendi yaşantısı yoluyla kasıtlı olarak istendik değişiklikler meydana getirme süreci olarak tanımlanan eğitimin en önemli unsurlarından birisi de ölçme ve değerlendirmedir (Demirel, 2006). Ölçme ve değerlendirme birçok amaç için yapılmaktadır; bu amaçlar, öğrencilerin başarı düzeylerini, öğrenme ihtiyaçlarını ve eksikliklerini, hazır bulunuşluluk seviyelerini, ilgi ve yeteneklerini belirlemek olarak söylenebilir (Kaşıkçı, 
Bolat, Değirmenci ve Karamustafaoğlu, 2015). Ölçme ve değerlendirme öğrencilerin kazanması amaçlanan bilgiyi elde edip etmediğini belirlemekle birlikte, eğitim sisteminin ürünü olan çıktılara bakarak sistemin işleyişinin izlenmesine, kontrol edilmesine ve gelişiminin sağlanmasına yardımcı olmaktadır (Koğar ve Aygün, 2015).

Öğrenci başarı durumlarını belirleyen ve ölçme denilince ilk akla gelen sınavlar, çeşitli ölçme araçları ile yapılabilir. Bu araçlar, çoktan seçmeli testler, uzun cevap gerektiren sınavlar, kısa cevaplı testler, sözlü yoklamalar ya da çeşitli performans testleri şeklinde olabilmektedir (Semerci, 2007). Yapılan sınavlarla eğitim sistemimizde ön görülen kazanımların bireylerde ne kadar gerçekleşip gerçekleşmediğinin belirlenmesi ve bu sınavlar neticesinde alınan puanlarla öğrencilerin bir üst eğitim kurumuna yerleştirilmesi sağlanmaktadır. Öğrencileri seçmek amacıyla öğretim kademeleri arasındaki geçişlerde uygulanmakta olan sınavlara ihtiyaç duyulmasının bazı nedenleri vardır. Bu nedenlerden birisi, ilgili kademedeki eğitim kurumlarına girmek için başvuran öğrenci sayısının kurumun açtığı kontenjandan fazla olması, bir diğeri ise eğitim kurumlarının kendilerinde eğitim-öğretim görmek için başvuru yapan öğrenciler arasından en uygun olanını seçmek istemesidir (Kutlu ve Karakaya, 2007).

Ülkemizde öğrenci başarısının ölçülmesi yerel ve merkezî sınavlarla gerçekleştirilmektedir. Bunlar, öğrencilerin formal eğitim aldıkları okullarda öğretmenleri tarafindan değerlendirilmeleri (yerel değerlendirme) ve merkezî kurumlar tarafından (merkezî) değerlendirilmeleri şeklindedir (Çepni, Özsevgeç ve Gökdere, 2003). Yerel ölçme ve değerlendirme, öğretmenler tarafından öğrencilerin sınıf içi başarı durumlarını tespit etmek amacıyla yapılırken; merkezî ölçme ve değerlendirme, orta öğretim ve yükseköğretim kurumlarına öğrenci seçmek için Millî Eğitim Bakanlığı (MEB) ve Öğrenci Seçme ve Yerleştirme Merkezi (ÖSYM) tarafından yapılmaktadır. Okullarda yapılan yerel ölçme-değerlendirmelerin neticesinde başarılı bulunmuş öğrencilerin bir üst kademeye geçebilmek için merkezî ölçme-değerlendirme sınavlarına girmeleri gerekmektedir. Bu sürecin en önemli örneklerinden biri ise temel eğitimden ortaöğretime geçiş sürecidir. Tarihsel gelişimi itibariyle bu süreç, ülkemizde 1950'li yıllara uzanmaktadır. Daha önceleri ilkokul sonrası uygulanan merkezî sınavlarla bir üst kademeye geçiş yapılırken 1999 yılından itibaren sekiz yıllık zorunlu eğitim kapsamında bu durum sekizinci 
sınıf öğrencilerinin merkezî sınava girmesi şeklinde uygulanmaktadır (Birinci, 2014). MEB'in liselere geçişlerde uyguladığı bu sınavların geçmişten günümüze zaman içerisinde değişimlere uğradığı, yapılan seçme sınavlarının bir kısmının uygulamadan kaldırıldığı, bir kısmı için yenilenme yoluna gidildiği ve açılan kurumlarla ilişkili olarak yeni sınavların eklendiği görülmektedir. Türkiye'de ortaöğretime geçişte, öğrenci seçme ve yerleştirme sürecinde temel belirleyici merkezî sınavlar olmasına rağmen, sınavların yapısı, içeriği, puan hesaplama yöntemleri gibi konularda bir istikrar sağlanamamıştır. Merkezî sınavların; eğitim sistemi, öğrenci ve veliler üzerindeki olumsuz etkilerini azaltmak hatta yok etmek gerekçesi ile 1998-2012 y1lları arasında dört farklı sınav sistemi uygulanmıştır. Bunlar; Liselere Giriş Sınavı (LGS), Ortaöğretim Kurumları Seçme ve Yerleştirme Sınavı (OKS), 6, 7 ve 8. siniflarda yapilan SBS ve en son sadece 8. sinifta uygulanan SBS (MEB, 1998, 2003, 2005, 2008) sinavlarıdır (Çelik, 2011).

Son olarak ise ülkemizde, 2013-2014 eğitim-öğretim yılından itibaren, Temel Eğitimden Orta Öğretime Geçiş (TEOG) sınavı uygulanmaktadır. Bu sınavın uygulamaya konulma gerekçesi öğrenci, öğretmen ve okul ilişkisini güçlendirme, başarı değerlendirmesini sürece yayma, eğitim sürecinde öğretmenlerin ve okulun rolünü daha etkin kılma olarak görülmektedir (Kaş1kç1, 2015). MEB tarafından yapılan TEOG sınavı 8. sınıf öğrencilerine ilk dönem kasım ayı, ikinci dönem nisan ayında, iki farklı günde yapılmaktadır. İlk gün Türkçe, Matematik, Din Kültürü ve Ahlâk Bilgisi; ikinci günde ise Fen ve Teknoloji, TC İnkılap Tarihi ve Atatürkçülük ve Yabancı Dil derslerinden oluşan sınavlar kırkar dakikalık toplam altı oturumdan oluşmaktadır. Sınavda yer alan sorular çoktan seçmelidir ve sınav, yanlış cevaplar doğru cevap sayısını etkilemeyecek şekilde düzenlenmiştir. İki ayrı dönemde yapılan bu sınav sonuçları iki sınavı olan derslerde birinci, üç sınavı olan derslerde ise ikinci sınav yerine geçmektedir (MEB, 2013). Öğrenciler bu sınavlara giremedikleri takdirde geçerli gerekçelerini belgelendirmek ve bildirmek suretiyle mazeret sınavlarına girebilmektedirler. Yeni sinav sistemi uygulanmaya başlamadan önce zihinlerde oluşan soruları giderebilmek üzere birçok tanıtımlar yapılmış ve ilgili alanlarda örnek sorular yayınlanmıştır (Birinci, 2014). Birinci ve ikinci dönem uygulanan TEOG sınavı puan ortalamaların \%70'i ile diploma puanının \%30'u alınarak orta öğretime yerleştirme puanı (OYP) hesaplanmaktadır (MEB, 2013). Türk Millî Eğitim Sistemi’nde birçok öğrencinin akademik hayatına nasıl devam edeceği, okul 
başarı puanları ve merkezî sınavlardan aldıkları sonuçlara göre belirlenmektedir. Bu durumla bağlantılı olarak genel anlamda öğrencilerin hayatında iki önemli merkezî sınavdan bahsedilebilir. Bunlardan ilki öğrencilerin ilköğretim eğitimleri sonunda hangi tür liselere gideceğini belirleyen Temel Eğitimden Ortaöğretime Geçiş Sınavı (TEOG), ikincisi ise ortaöğretim eğitimleri sonunda üniversiteye girebilmenin en önemli belirleyicisi olan Lisans Yerleştirme Sınavı (LYS)'dır. Her iki sınav da öğrencilerin gelecekteki hayatlarını belirleme adına önemli rollere sâhiptir. Bu şekilde düşünüldügünde hem TEOG hem de LYS öğrencilerin ve ebeveynlerin hayatlarında önemli bir yere sahiptir (İnanç ve Hanımoğlu, 2011).

Ortaöğretime giriş sınavları, öğrenci ve aileler açısından yeterli düzeyde fizikî imkânlarla donatılmış, öğrencilerine yüksek kalitede eğitim-öğretim sunan iyi bir lise ve iyi bir üniversite dolayısıyla geçerli bir mesleğin hazırlayıcısı olduğu için büyük önem taşımaktadır (Sarıer, 2010). 8. sınıfta yapılan TEOG sınavı öğrenciler için önemli bir sınav olarak görülmekte, okullar, ebeveynler ve öğrenciler bu sınava yönelik olarak çeşitli çalışmalar yapmaktadırlar. Öğrencilerin TEOG sınavını ne şekilde algıladıkları hem kaygı durumlarını hem de motivasyon düzeylerini ortaya koymada ve etkili biçimde rehberlik hizmetlerini yürütmede önemli bir veri kaynağ1dır. Bu bağlamda 8. sınıf öğrencilerinin TEOG algılarının belirlenmesi sınav kaygısını önlemek için yapılacak uygulamalara ve rehberlik hizmetlerine $1 s ̧ 1 k$ tutabilir. Öğrencilerin algıları ve bu algılamalarının nedenleri net biçimde ortaya konabilir. İlgili alanyazın tarandığında bu konuda yapılmış herhangi bir araştırmaya rastlanmamıştır. Bu bağlamda öğrencilerin algılarının metaforik olarak incelenmesinin anlamlı olacağı düşünülmüştür. Çünkü öğrencinin düşünmesini sağlayan ve etkin kılan yollardan biri metafordur (Oğuz, 2005, s.582). Senemoğlu (2005, s.564), bilginin adlandırılması sürecinde oluşan yeni bilgilere metafor demiştir. Metafor bir kavramı bir başka kavrama benzeterek anlatmaktır. Sözkonusu iki kavramın birbirine benzerliği az olabilir ancak birini çok iyi biliyor olmak diğerini daha iyi anlama olanağını sağlamaktadır. (Ocak ve Gündüz, 2006, s.295). Metaforların bu özelliği göz önünde bulundurularak bu araştırmanın temel amacı 8. sınıf öğrencilerinin TEOG sınavına yönelik algılarının metaforik açıdan incelenmesidir. 
Bu temel amaca bağlı olarak aşağıdaki sorulara yanıt aranacaktır:

1. Öğrencilerin TEOG sınavına yönelik metaforları nelerdir?

2. Öğrencilerin TEOG sınavına yönelik algıları, okulun bulunduğu yere (köy-ilçe-il merkezî) göre nasıl değişiklik göstermektedir?

\section{Yöntem}

$\mathrm{Bu}$ araştırmada nitel araştırma yöntemi kapsamında olgu bilim (fenomenoloji) deseni kullanılmıştır. Olgu bilim çalışmalarında genellikle bir olguya ilişkin bireysel algıların ortaya çıkarılması ve yorumlanması amaçlanır (Yıldırım ve Şimşek, 2011). Hayatımız boyunca iletişim kurduğumuz sürece birçok yeni kavram öğrenir ve bu kavramları zihnimizde anlamlandırmaya çalışırız. Bu süreç daha önceden bilinen bilgilerimizle benzerlik kurularak gerçekleştirilmişse kolay, kurulamamışsa da zor ve yorucu olabilir (Şahin, 2013, s.313).

\section{Katılımcilar}

$\mathrm{Bu}$ çalışma, 2015-2016 eğitim-öğretim yılında Afyonkarahisar il merkezi, ilçeleri ve köylerinde yer alan 8 devlet ortaokulunun 8 . sinıfına devam etmekte olan toplam 267 öğrenci ile gerçekleştirilmiştir.

Örneklem büyüklügü̈; ne bulmak istendiğine, neden bulunmak istendiğine, bulunanların nasıl kullanılacağına ve çalışmak için (zamana bağlı olarak) hangi tür kaynakların olduğuna bağlıdır (Patton, 2002, s.244). Bu nedenle araştırma yapılacak okullar ve araştırmaya katılacak öğrenciler seçilirken bu durum dikkate alınmalıdır. Buna bağlı olarak bu araştırmada, amaçlı örnekleme yöntemlerinden maksimum çeşitlilik örneklemesi kullanılmıştır. Amaçlı örnekleme yöntemleri zengin bilgiye sâhip olduğu düşünülen durumların derinlemesine çalışılmasına olanak vererek pek çok durumda, olgu ve olayların keşfedilmesinde ve açıklanmasında yararlı olur (Yıldırım ve Şimşek, 2011). Bu araştırmada köy, ilçe ve il merkezinde, öğrencilerin sâhip olduğu metaforların benzerlik ve farklılık durumlarını görmek amacıyla maksimum çeşitlilikten yararlanılmıştır. Araştırma grubunu oluşturan öğrencilerin 83'ü il merkezi, 94'ü ilçe merkezi ve 90'1 ise köy ve kasabada öğrenim görmekte olan öğrencilerdir. 
Tablo 1. Katılımcıların Cinsiyet ve Okullarının Bulunduğu Yerleşim Birimine Göre Dağglımı

\begin{tabular}{|c|c|c|c|c|c|c|c|c|}
\hline \multirow[b]{3}{*}{ Cinsiyet } & \multicolumn{6}{|c|}{ Okulun Bulunduğu Yerleşim Birimi } & \multirow{2}{*}{\multicolumn{2}{|c|}{ Toplam }} \\
\hline & \multicolumn{2}{|l|}{ Köy } & \multicolumn{2}{|c|}{ İlçe } & \multicolumn{2}{|c|}{ İl Merkezi } & & \\
\hline & $f$ & $\%$ & $f$ & $\%$ & $f$ & $\%$ & $f$ & $\%$ \\
\hline K1z & 52 & 57.78 & 38 & 40.43 & 40 & 48.19 & 130 & 48.69 \\
\hline Erkek & 38 & 42.22 & 56 & 59.57 & 43 & 51.81 & 137 & 51.31 \\
\hline Toplam & 90 & 100.00 & 94 & 100.00 & 83 & 100.00 & 267 & 100.00 \\
\hline
\end{tabular}

\section{Geçerlik ve Güvenirlik Çalışması}

Araştırmanın geçerliğini sağlamak amacıyla ulaşılan kavramsal kategoriler altında verilen metaforların ilgili kavramsal kategoriyi temsil edip etmediğini test etmek için uzman görüşlerine başvurulmuştur. $\mathrm{Bu}$ amaç doğrultusunda araştırmacılar dişında nitel araştırma konusunda deneyimli olan uzmanlara bütün metaforlar $(\mathrm{f}=240)$ ve oluşturulan bütün kavramsal kategorilerin $(\mathrm{N}=6)$ adlarını ve özelliklerini içeren bir liste verilmiştir. Uzmanlar metaforların oluşturulan kategorilere uygun olup olmadığını incelemişlerdir. Bu incelemeler sonunda araştırmacılar ile uzmanların kategorilerle ilgili görüş birliği ve ayrılıkları karşılaştırılmış ve Miles ve Huberman'ın (1994) güvenirlik formülü kullanılarak araştırmanın güvenirliği \%88 olarak hesaplanmıştır.

\section{Verilerin Analizi}

$\mathrm{Bu}$ araştırmada verilerin analizinde içerik analizinden yararlanılmıştır. Katılımcılardan "Bana göre TEOG ....'dır/dir", "Çünkü, ...” ifadelerinin yazılı olduğu kağıtlardaki noktalı yerlere kendi sözcük ve cümlelerini yazmaları istenmiştir. Toplanan verilerin analiz süreci üç merhalede gerçekleştirilmiştir. Öncelikle öğrencilerin kullandıkları metaforlar kaynaklarına göre tablolaştırılmıştır. Sonra metaforun konusu ve kaynağı arasındaki ilişki bakımından ayrıntılı bir incelemeye tabi tutulmuştur. Metaforun kaynağını içermeyen kâğıtlar ve gerekçesi sunulmayan metaforlar ayıklanmıştır. Bu ayıklama işlemi sonunda katılımcılar tarafından ifadeleri eksik bırakılmış 27 kâğıt analiz dışına alınarak, kalan 240 kâğıt üzerinden içerik analizi ile kategorileştirme başlatılmıştır. Üçüncü aşamada, ayıklama işleminden sonra, içerik analizi yapılarak belli ortak özelliklere sâhip metaforlar kategorileştirilmiştir. Ocak ve Gündüz (2006), Güveli, İpek, Atasoy ve Güveli (2011), İlter (2015) tarafından yapılan araştırmalarda da metaforların analizinde 
benzer bir yaklaşım kullanılmıştır. Bu araştırma kapsamında, ayıklama işlemini takiben yapılan analizler sonucunda metaforlar 6 kategoriye ayrılmıştır. Bu kategoriler emek, zorlanma, beklenti, önem, hedef, memnuniyet şeklinde ortaya çıkmıştır. Oluşan kategorilere ilişkin örnek metaforlar sunulurken katılımcılara verilen kod isimler kullanılmıştır.

\section{Bulgular}

Katılımcılar tarafından kullanılan metaforlara ilişkin kategoriler emek, zorlanma, beklenti, önem, hedef, memnuniyet şeklindedir. Bu metaforların sözü edilen kategorilere dağılımına ilişkin frekans değerleri Tablo 2'de verilmiştir.

Tablo 2. TEOG Sınavına İlişkin Üretilen Metaforların Kategorilere Göre Dağılımı

\begin{tabular}{lc}
\hline Kategoriler & $\boldsymbol{f}$ \\
\hline Zorlanma & 71 \\
Önem & 61 \\
Hedef & 53 \\
Beklenti & 32 \\
Emek & 16 \\
Memnuniyet & 7 \\
\hline Toplam & 240 \\
\hline
\end{tabular}

Yukarıdaki tablo incelendiğinde, araştırmaya katılan öğrencilerin TEOG sınavına ilişkin olarak en fazla sayıda zorlanma kategorisinde (67), en az sayıda ise memnuniyet kategorisinde (7) metafor ürettikleri görülmektedir. $\mathrm{Bu}$ durum, TEOG sınavının öğrencilerde stres ve korkuya neden olduğunu gösterir niteliktedir.

Zorlanma kategorisinde öğrencilerin TEOG sınavı nedeniyle duygusal sorunlar yaşadığı görülmektedir. Duygusal sorun yaşanmasına neden olan psikolojik etkenler; stres, kaygı ve korku şeklinde görülmektedir. Hedef kategorisi incelendiğinde, öğrencileri hedefe götürecek bir yolun varlığı ya da hedefe ulaştıracak bir aracın söz konusu olduğu dikkat çekmektedir. Memnuniyet kategorisinde ise öğrencilerin bu durumdan keyif aldıkları ya da eğlendikleri görülmektedir. 


\section{Köy Okullarında Eğitim-Öğretim Gören Öğrencilerin Geliştir- dikleri Metaforlar}

Araştırmaya katılan köy okullarında öğrenim görmekte olan öğrenciler TEOG sınavına ilişkin toplam 84 metafor geliştirmişlerdir. Öğrencilerin geliştirdikleri metaforların kategorilere göre dağılımına ilişkin frekans değerleri Tablo 3'te verilmiştir.

Tablo 3. Köy Okullarında Eğitim-Öğretim Gören Öğrencilerin TEOG Sınavına İlişkin Ürettikleri Metaforların Kategorilere Göre Dağılımı

\begin{tabular}{ll}
\hline Kategoriler & $\boldsymbol{f}$ \\
\hline Önem & 30 \\
Hedef & 25 \\
Zorlanma & 19 \\
Beklenti & 6 \\
Memnuniyet & 4 \\
\hline Toplam & 84 \\
\hline
\end{tabular}

Tablodan anlaşılacağı üzere, araştırmaya katılan köy öğrencilerinin TEOG sınavına ilişkin en çok ürettikleri metaforun (28) önem kategorisinde, en az ürettikleri metaforun da (4) memnuniyet kategorisinde bulunduğu görülmektedir. Buna göre, köy öğrencilerinin TEOG sınavını daha çok önem veya önemsizlik açısından değerlendirdikleri görülmektedir.

Köy okullarında eğitim-öğretim gören öğrencilerin önem kategorisine ilişkin ürettikleri metaforların frekans dağılımı Tablo 4'te verilmiştir.

Tablo 4'e göre, köy öğrencilerinin önem kategorisinde 30 metafor geliştirdikleri görülmektedir. Bu kategoride öğrencilerin yarısı (15) TEOG sınavı için "önemli" şeklinde metafor üretmişlerdir.

Öğrencilerden İlyas, TEOG sınavı için şöyle bir cümle kurmuştur: "Bana göre TEOG önemlidir. Çünkü benim hangi liseye gideceğimi belirleyen güzel ve önemli bir sinavdır." 
Tablo 4. Köy Okullarında Eğitim-Öğretim Gören Öğrencilerin Önem Kategorisine İlişkin Ürettikleri Metaforlar

\begin{tabular}{ll}
\hline Metafor adı & $\boldsymbol{f}$ \\
\hline Önemli & 15 \\
Hayatı belirleyen sınav & 5 \\
Acı biber & 1 \\
Hayatın önemi & 1 \\
Gereksiz & 1 \\
Tecrübe & 1 \\
Kitap & 1 \\
İyi & 1 \\
Gerekli & 1 \\
Geleceği belirleyen & 1 \\
Berbat bir uygulama & 1 \\
Otobüs & 1 \\
\hline Toplam & 30 \\
\hline
\end{tabular}

Köy okullarında eğitim-öğretim gören öğrencilerin hedef kategorisine ilişkin olarak ürettikleri metaforların frekans dağılımı Tablo 5'te verilmiştir.

Tablo 5. Köy Okullarında Eğitim-Öğretim Gören Öğrencilerin Hedef Kategorisine İlişkin Ürettikleri Metaforlar

\begin{tabular}{ll}
\hline Metafor adı & $f$ \\
\hline Hayat & 6 \\
Gelecek & 4 \\
Yarış & 2 \\
Hayat sınavi & 1 \\
Güzel & 1 \\
Yol & 1 \\
Kader çizgisi & 1 \\
Sirat köprüsü & 1 \\
Nöbetçi & 1 \\
Köprü & 1 \\
Kilitli kapı & 1 \\
Adım & 1 \\
Hayatı belirleyen şey & 1 \\
Anahtar & 1 \\
Sinav & 1 \\
Yolculuk & 1 \\
\hline Toplam & 25 \\
\hline
\end{tabular}


Araştırmaya katılan öğrencilerin zorlanma kategorisine ilişkin olarak ürettikleri metaforların frekans dağılımına Tablo 6 'da yer verilmiştir.

Tablo 6. Köy Okullarında Eğitim-Öğretim Gören Öğrencilerin Zorlanma Kategorisine İlişkin Ürettikleri Metaforlar

\begin{tabular}{ll}
\hline Metafor adı & $\boldsymbol{f}$ \\
\hline Heyecan & 3 \\
Zor bir sınav & 3 \\
Stres & 2 \\
Baş ağrısı & 2 \\
Korkulu rüya & 2 \\
Gideceğin okulu belirler & 1 \\
IŞīD & 1 \\
Adrenalin & 1 \\
Korku & 1 \\
Hayvan & 1 \\
Putin & 1 \\
Mahşer yeri & 1 \\
\hline Toplam & 19 \\
\hline
\end{tabular}

Tablo incelendiğinde, öğrencilerin bu kategoride 19 metafor ürettikleri ve TEOG sınavını en çok heyecan ve zor bir sınava benzettiği görülmektedir.

Öğrencilerden Hilal'in duyduğu kaygıya yönelik kurduğu cümle şu şekildedir: "Bana göre TEOG korkulu rüya gibidir. Çünkü çalışmazsam hayatımı bitirir."

Diğer bir öğrenci Rümeysa'nın strese yönelik kurduğu cümle şu şekildedir: "Bana göre TEOG Işid gibidir. Çünkü teröristlerin bitmediği gibi sinavda bitmiyor."

Köy okullarında eğitim-öğretim gören öğrencilerin beklenti kategorisine ilişkin ürettikleri metaforların frekans dağılımına Tablo 7'de yer verilmiştir.

Öğrencilerin beklenti kategorisinde 6 metafor geliştirdikleri görülmektedir. Beklenti kategorisinde en çok gelecek benzetmesinde bulunulduğu belirlenmiştir. 
Tablo 7. Köy Okullarında Eğitim-Öğretim Gören Öğrencilerin Beklenti Kategorisine İlişkin Ürettikleri Metaforlar

\begin{tabular}{ll}
\hline Metafor adı & $\boldsymbol{f}$ \\
\hline Gelecek & 2 \\
Aydınlık & 1 \\
Zor & 1 \\
Felaket & 1 \\
Hüzün & 1 \\
\hline Toplam & 6 \\
\hline
\end{tabular}

Beklenti kategorisinde İsmail isimli öğrencinin kurduğu cümle şu şekildedir: "Bana göre TEOG aydınlıktır. Çünkü TEOG benim hayatımı değiştirecek bir sinavdır, ya beni yükseltecek ya da düşürecektir."

Köy okullarında eğitim-öğretim gören öğrencilerin memnuniyet kategorisine ilişkin ürettikleri metaforların frekans dağılımına Tablo 8'de yer verilmiştir.

Tablo 8. Köy Okullarında Eğitim-Öğretim Gören Öğrencilerin Memnuniyet Kategorisine İlişkin Ürettikleri Metaforlar

\begin{tabular}{ll}
\hline Metafor adı & $\boldsymbol{f}$ \\
\hline Heyecan & 4 \\
\hline Toplam & 4 \\
\hline
\end{tabular}

Öğrencilerin memnuniyet kategorisinde 4 metafor geliştirdikleri görülmektedir. Memnuniyet kategorisinde 4 öğrencinin geliştirdiği tek metafor heyecan metaforudur.

Araştırmaya katılan öğrencilerden Halil memnuniyet kategorisinde şöyle bir cümle kurmuştur: "Bana göre TEOG heyecandır. Çünkü TEOG sinavina girmeden önce hiç heyecan, mutluluk yoktu. Ama sınava gireceğim sınıfa girdiğimde sanki heyecandan kalbim yerinden firlayacak gibi oldu."

\section{İlçe Okullarında Eğitim-Öğretim Gören Öğrencilerin Geliştirdik- leri Metaforlar}

Araştırmaya katılan ilçe ortaokullarında eğitim-öğretim gören öğrenciler, TEOG sınavı kavramına ilişkin toplam 80 metafor geliştirmişlerdir. Bu 
öğrencilerin geliştirdikleri metaforların, oluşturulan 7 kategoriye dağılımına ilişkin frekans dağılımı Tablo 10' da verilmiştir.

Tablo 10. İlçe Okullarında Eğitim-Öğretim Gören Öğrencilerin TEOG S1navı Hakkında Ürettikleri Metaforların Kategorilere Göre Dağılımı

\begin{tabular}{ll}
\hline Kategoriler & $\boldsymbol{f}$ \\
\hline Zorlanma & 25 \\
Hedef & 22 \\
Önem & 15 \\
Beklenti & 8 \\
Emek & 9 \\
Memnuniyet & 1 \\
\hline Toplam & 80 \\
\hline
\end{tabular}

Tablodan anlaşılacağı üzere, öğrencilerin TEOG sınavına ilişkin olarak ürettikleri metaforların büyük çoğunluğunun (25) zorlanma kategorisinde bulunan metaforlar olması, öğrencilerin TEOG sinav1 nedeniyle stres altında olduklarını dolayısıyla sınavdan dolayı kaygı ve korku yaşadıklarını işaret etmektedir.

İlçe okullarında eğitim-öğretim gören öğrencilerin zorlanma kategorisine ilişkin ürettikleri metaforların frekans dağ 1 lımına Tablo 11 'de yer verilmiştir.

Tablo 11'de yer alan bilgiler incelendiğinde, öğrencilerin zorlanma kategorisine ilişkin olarak 28 metafor ürettikleri görülmektedir. Bu kategoride öğrenciler, TEOG sınavını en çok strese benzetmektedirler.

Bu kategoride Mustafa isimli öğrenci yaşadığı stresten dolayı şöyle bir cümle kurmuştur: "Bana göre TEOG kibrittir. Çünkü TEOG, sinav zamanı beynimizi yaklyor."

Kerem isimli öğrenci yaşadığı kaygıyı şu şekilde dile getirmiştir: "Bana göre TEOG tedirginliktir. Çünkü sinavda çok panik oluyorum. Ya kitapçı̆̆ yanlış işaretlersem, ya çok düşük bir puan alırsam, ya heyecandan dolayı bildiğim şeyleri de unutursam endişesi oluyor." 
Tablo 11. İlçe Okullarında Eğitim-Öğretim Gören Öğrencilerin Zorlanma Kategorisine İlişkin Ürettikleri Metaforlar

\begin{tabular}{ll}
\hline Metafor adı & $\boldsymbol{f}$ \\
\hline Stres & 4 \\
Kâbus & 2 \\
Maraton & 1 \\
İgne vurulmak & 1 \\
İskence & 1 \\
Kibrit & 1 \\
Kara bulut & 1 \\
Nükleer santral & 1 \\
Bilinçaltı kâbusu & 1 \\
Psikolojik etki & 1 \\
Hayat kaybı & 1 \\
Zorlayıcı & 1 \\
Korku dolu & 1 \\
Gerginlik & 1 \\
Tedirginlik & 1 \\
Kötü & 1 \\
Kötü bir sistem & 1 \\
Stresli bir süreç & 1 \\
Stresli sinav & 1 \\
Heyecan & 1 \\
Dozer & 1 \\
Kâbus & 1 \\
Modifikasyon & 1 \\
Rus uçağının düşürülmesi & 1 \\
\hline Toplam & 1 \\
\hline & 1 \\
\hline & 1 \\
\hline
\end{tabular}

İlçe okullarında eğitim-öğretim gören öğrencilerin hedef kategorisine ilişkin olarak ürettikleri metaforların frekans dağılımı Tablo 12'de verilmiştir.

Tablo 12'deki veriler incelendiğinde, araştırmaya katılan öğrencilerin bu kategoriye ilişkin 22 metafor geliştirdikleri görülmektedir. Öğrenciler bu 
kategoride, TEOG sınavını en çok geleceğe hazırlayan sınava benzetmişlerdir.

Beyza isimli öğrencinin kurduğu cümle şu şekildedir: "Bana göre TEOG bir köprüdür. Çünkü ileride hangi liseye gideceğimizi ve ne olacağlmızı gösterir."

Tablo 12. İlçe Okullarında Eğitim-Öğretim Gören Öğrencilerin Hedef Kategorisine İlişkin Ürettikleri Metaforlar

\begin{tabular}{ll}
\hline Metafor adı & $\boldsymbol{f}$ \\
\hline Geleceği hazırlayan sınav & 4 \\
Köprü & 3 \\
Araba & 2 \\
Hayat köprüsü & 2 \\
Dağ & 1 \\
Baraj & 1 \\
Uzun yol & 1 \\
Yardımcı & 1 \\
Kale & 1 \\
Rehber & 1 \\
Yol & 1 \\
Gelecek için atılan adım & 1 \\
Çift yönlü yol & 1 \\
Dal & 1 \\
Hayat & 1 \\
\hline Toplam & 22 \\
\hline
\end{tabular}

İlçe okullarında eğitim-öğretim gören öğrencilerin önem kategorisine ilişkin ürettikleri metaforların frekans dağılımına Tablo 13'te yer verilmiştir.

Öğrencilerin önem kategorisinde 15 metafor geliştirdikleri ve TEOG sınavını önemli bir şeye benzettikleri görülmektedir. 
Tablo 13. İlçe Okullarında Eğitim-Öğretim Gören Öğrencilerin Önem Kategorisine İlişkin Ürettikleri Metaforlar

\begin{tabular}{ll}
\hline Metafor adı & $\boldsymbol{f}$ \\
\hline Önemli & 6 \\
Gelecek & 4 \\
Gereksiz & 2 \\
Sorumluluk & 1 \\
Gelecek için önemli & 1 \\
Dönüm noktası & 1 \\
\hline Toplam & 15 \\
\hline
\end{tabular}

Fatma isimli öğrenci bu kategoride şöyle bir cümle kurmuştur: "Bana göre TEOG çok önemlidir. Çünkü hayatımızı belirleyecek bir sinavdır. Bir daha girme şansı olmadiğı için çok önemlidir."

Ali isimli öğrencinin bu kategoride kurduğu cümle şu şekildedir: "Bana göre TEOG saçmadır. Çünkü biz sinavdayken 5., 6. ve 7. sınıf öğrencileri tatil yaptılar. Bence bu sinava hiç gerek yok."

Araştırmaya katılan öğrencilerin beklenti, emek ve memnuniyet kategorilerine ilişkin ürettikleri metaforların frekans dağılımına aşağıdaki tablolarda yer verilmiştir.

Tablo 14. İlçe Okullarında Eğitim-Öğretim Gören Öğrencilerin Beklenti Kategorisine İlişkin Ürettikleri Metaforlar

\begin{tabular}{ll}
\hline Metafor adı & $\boldsymbol{f}$ \\
\hline Gen & 1 \\
Düşünce farklılığı & 1 \\
Hayat & 1 \\
Zor bir sınav & 1 \\
\hline Toplam & 4 \\
\hline
\end{tabular}


Tablo 15. İlçe Okullarında Eğitim-Öğretim Gören Öğrencilerin Emek Kategorisine İlişkin Ürettikleri Metaforlar

\begin{tabular}{ll}
\hline Metafor adı & $\boldsymbol{f}$ \\
\hline Doğal seçilim & 3 \\
Beceri & 1 \\
Yemek pişirmek & 1 \\
Zorlaştırılma & 1 \\
Canavar & 1 \\
Tarla & 1 \\
Kurtuluş savaşı & 1 \\
\hline Toplam & 9 \\
\hline
\end{tabular}

Tablo 16. İlçe Okullarında Eğitim-Öğretim Gören Öğrencilerin Memnuniyet Kategorisine İlişkin Ürettikleri Metaforlar

\begin{tabular}{ll}
\hline Metafor adı & $\boldsymbol{f}$ \\
\hline Çikolata & 1 \\
\hline Toplam & 1 \\
\hline
\end{tabular}

Tablolar incelendiğinde beklenti kategorisinde 4 metafor, emek kategorisinde 9 metafor ve memnuniyet kategorisinde ise sadece 1 metafor geliştirildiği görülmektedir. Öğrencilerin, TEOG sınavının beklenti kategorisindeki bütün benzetimlerinin eşit sayıda olduğu, emek kategorisinde en çok doğal seçilime benzettiği ve memnuniyet kategorisinde de sadece çikolataya benzettiği görülmektedir.

Beklenti kategorisinde Kağan isimli öğrencinin kurduğu cümle şu şekildedir: "Bana göre TEOG Rus uçağının düşürülmesidir. Çünkü TEOG angajman kuralları uyguladı. Biz de düştük, ikinci TEOG'da biz angajman uygulayacağız."

Büşra isimli öğrenci ise bu kategoride şöyle bir cümle kurmuştur. “Bana göre TEOG düsünce farklılığıdır. Çünkü TEOG aslında herkesin nasıl olmak, nasıl düşünmek istiyorsa hayatına ona göre şekil vermesidir."

Beceri kategorisinde Fatma'nın kullandığı cümle ise şöyledir: "Bana göre TEOG doğal seçilimdir. Çünkü çalışan kazaniyor, çalışmayan kaybe- 
diyor yani TEOG çalışkanı seçiyor ve hayata bağllyor; fakat çalışmayanı yani kaybedeni sana hayatta başarılar, deyip yolluyor."

\section{İl Merkezi Okullarında Ĕgitim-Öğretim Gören Öğrencilerin Ge- liştirdikleri Metaforlar}

Araştırmaya katılan, il merkezinde öğrenim görmekte olan ortaokul 8. sınıf öğrencileri TEOG sınavı hakkında 76 metafor geliştirmişlerdir. Bu öğrencilerin geliştirdikleri metaforların oluşturulan 7 kategoriye dağılımına ilişkin frekans değerleri Tablo 17'de verilmiştir.

Tablo 17. İl Merkezi Okullarında Eğitim-Öğretim Gören Öğrencilerin TEOG Sınavı Hakkında Ürettikleri Metaforların Kategorilere Göre Dağılımı

\begin{tabular}{ll}
\hline Kategoriler & $\boldsymbol{f}$ \\
\hline Zorlanma & 23 \\
Beklenti & 21 \\
Önem & 17 \\
Emek & 7 \\
Hedef & 6 \\
Memnuniyet & 2 \\
\hline Toplam & 76 \\
\hline
\end{tabular}

Tablo incelendiğinde, il merkezinde öğrenim görmekte olan öğrencilerin TEOG sınavına ilişkin olarak ürettikleri metaforların büyük çoğunluğunu zorlanma (23) ve beklenti (21) kategorilerinde bulunan metaforlar oluşturmaktadır. Buna göre il merkezindeki 8. sınıf öğrencileri için TEOG sınavı hem stres, kaygı ve korku oluşturmakta hem de öğrencilerin olumlu veya olumsuz beklenti içinde olmalarına neden olmaktadır.

Araştırmaya katılan öğrencilerin zorlanma kategorisine ilişkin olarak ürettikleri metaforların frekans dağılımına Tablo 18'de yer verilmiştir.

Öğrenciler bu kategoride 23 metafor kullanmış ve TEOG sınavı için en çok zor olduğuna dâir benzetmede bulunmuşlardır.

Araştırmaya katılan Dilara isimli öğrencinin bu kategorideki kaygısı şu şekildedir. "Bana göre TEOG sılıntıdır. Çünkü sınav öncesi aylarca aralıksız çalı̧̧ma, dinlenen dersler, çözülen testler, okunan kitaplar bunlar insanı 
yorar bir de üstüne stres ve beklenti. Bunların karşılığını stres ve dikkatsizlikten dolayı alamdım ve fazlasıyla yanlışım çıktı."

Tablo 18. İl Merkezi Okullarında Eğitim-Öğretim Gören Öğrencilerin Zorlanma Kategorisine İlişkin Ürettikleri Metaforlar

\begin{tabular}{ll}
\hline Metafor adı & $\boldsymbol{f}$ \\
\hline Zor & 7 \\
Kötü & 5 \\
Eziyetli bir sınav & 2 \\
Sikıntı & 2 \\
Korkunç & 1 \\
Sikıcı & 1 \\
Kötü bir uygulama & 1 \\
Ölüm & 1 \\
Önyargı & 1 \\
Gelecek sinavı & 1 \\
Haksızlık & 1 \\
\hline Toplam & 23 \\
\hline
\end{tabular}

Ali isimli öğrenci ise yaşadığı korkuyu şu şekilde ifade etmiştir: " $B a$ na göre TEOG çok korkunçtur. Çünkü ben çok panik oluyorum ve bu yüzden TEOG'dan çok korkuyorum. Ayrıca çok çelişkili ve zor bir sinavdır."

İl merkezi öğrencilerinin beklenti kategorisinde ürettikleri metaforların frekans dağılımı Tablo 19'da verilmiştir.

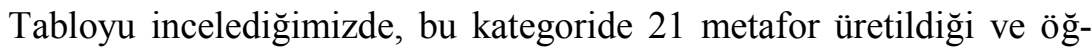
rencilerin yarıya yakınının (10) TEOG sınavını gelecek sınavına benzeterek ilişkilendirmede bulunduğu görülmektedir.

$\mathrm{Bu}$ kategoride Meral isimli öğrencinin kurduğu cümle şu şekildedir: "Bana göre TEOG geleceğimin sinavıdır. Çünkü o sinavla ben, benim geleceğim olan 4 senelik bir liseye gideceğim. Bu yüzden bu sınav benim için çok önemli, iyi bir sinav iyi bir gelecek, iyi bir not, iyi bir gelecektir." 
Tablo 19. İl Merkezi Okullarında Eğitim-Öğretim Gören Öğrencilerin Beklenti Kategorisine İlişkin Ürettikleri Metaforlar

\begin{tabular}{ll}
\hline Metafor adı & $\boldsymbol{f}$ \\
\hline Gelecek sınavı & 10 \\
Gelecek & 5 \\
Tercih & 2 \\
Şaşırtıcı & 1 \\
İyi & 1 \\
İlk basamak & 1 \\
Umut & 1 \\
\hline Toplam & 21 \\
\hline
\end{tabular}

İl merkezi öğrencilerinin önem kategorisinde ürettikleri metaforların frekans dağ $11 ı \mathrm{~m} ı$ Tablo 20'de verilmiştir.

Tablo 20. İl Merkezi Okullarında Eğitim-Öğretim Gören Öğrencilerin Önem Kategorisine İlişkin Ürettikleri Metaforlar

\begin{tabular}{ll}
\hline Metafor adı & $f$ \\
\hline Gereksiz bir şey & 3 \\
Önemli & 3 \\
Sikıcı & 2 \\
İyi bir yöntem & 2 \\
Avantaj & 2 \\
Saçma bir sınav & 2 \\
Şansa dayalı & 1 \\
Kolay & 1 \\
Heyecanlandırıcı & 1 \\
\hline Toplam & 17 \\
\hline
\end{tabular}

Tablo incelendiğinde, ögrencilerin önem kategorisinde 17 metafor geliştirdikleri görülmektedir. Buna göre il merkezi öğrencilerinin TEOG sınavını bu kategoride en çok önemli ve aynı miktarda gereksiz bir şeye benzettikleri belirlenmiştir.

İrem isimli öğrencinin bu kategoride kurduğu cümle şu şekildedir: "Bana göre TEOG sıkıcıdır. Çünkü bütün sene sadece ders çalışmak insanı 
yoruyor. Ve oyun oynamaya zaman kalmıyor. Sadece ders çalışmakta bireyi sikıyor."

Araştırmaya katılan il merkezi öğrencilerinin emek ve hedef kategorilerinde ürettikleri metaforların frekans dağılımı aşağıdaki tablolarda verilmiştir.

Tablo 21. İl Merkezi Okullarında Eğitim-Öğretim Gören Öğrencilerin Emek Kategorisine İlişkin Ürettikleri Metaforlar

\begin{tabular}{ll}
\hline Metafor adı & $\boldsymbol{f}$ \\
\hline Seviye belirleme & 2 \\
Hayat & 1 \\
Rahat bir sinav & 1 \\
Uygun bir sistem & 1 \\
Güzel & 1 \\
Belirleyici & 1 \\
\hline Toplam & 7 \\
\hline
\end{tabular}

Tablo 22. İl Merkezi Okullarında Eğitim-Öğretim Gören Öğrencilerin Hedef Kategorisine İlişkin Ürettikleri Metaforlar

\begin{tabular}{ll}
\hline Metafor adı & $\boldsymbol{f}$ \\
\hline Zorlu sınav & 2 \\
Kader sınavı & 1 \\
İlk köprü & 1 \\
Hayat kilidi & 1 \\
Lise & 1 \\
\hline Toplam & 6 \\
\hline
\end{tabular}

Tablolar incelendiğinde öğrencilerin emek kategorisinde 7, hedef kategorisinde ise 6 metafor geliştirdikleri görülmektedir. Öğrencilerin emek kategorisinde en çok seviye belirleme, hedef kategorisinde ise zorlu sinav benzetmesinde bulundukları belirlenmektedir.

Eymen isimli öğrencinin emek kategorisinde kullandığ 1 cümle şu şekildedir: "Bana göre TEOG güzeldir. Çünkü insanlar arasında seviyelerin oluşumu muhakkaktır. Bir yerden sonra insanların yapacağı meslek grupları 
ayrllmalıdır ve böylece insanların becerileri belli olmalıdır ki zaten TEOG bunu tam olarak karşılayamasa da yine de yeterlidir."

İl merkezi öğrencilerinin memnuniyet kategorisinde ürettikleri metaforların frekans dağılımı Tablo 23'te verilmiştir.

Tablo 23. İl Merkezi Okullarında Eğitim-Öğretim Gören Öğrencilerin Memnuniyet Kategorisine İlişkin Ürettikleri Metaforlar

\begin{tabular}{ll}
\hline Metafor adı & $\boldsymbol{f}$ \\
\hline Eziyet & 1 \\
Başımın tatlı belası & 1 \\
\hline Toplam & 2 \\
\hline
\end{tabular}

Tabloya göre öğrencilerin memnuniyet kategorisinde 2 metafor ürettikleri görülmektedir. Öğrenciler memnuniyet kategorisinde birer tane benzetim yaparak, eziyet ve başımın tatlı belası benzetmelerinde bulunmuşlardır.

Memnuniyet kategorisinde Azra isimli öğrencinin kurduğu cümle şu şekildedir: "Bana göre TEOG eziyettir. Çünkü çocukları eğitimden bezdirip korkutuyorlar üzüyorlar; ama ne bileyim keyif aldım hazırlanırken."

\section{Sonuç Tartışma ve Öneriler}

Ortaokul 8. sınıf öğrencilerinin TEOG sınavına ilişkin ürettikleri metaforları belirlemek amacıyla yapılan bu araştırmada, öğrenciler toplam 240 metafor üretmişlerdir. Bu metaforların 84'ü köyde, 80'i ilçede ve 76'sı da il merkezinde öğrenim gören öğrenciler tarafindan üretilmiştir.

Araştırmaya katılan ortaokul öğrencilerinin ürettikleri bu metaforlar emek, zorlanma, beklenti, önem, hedef, memnuniyet olmak üzere 6 kategoride toplanmıştır. Öğrenciler bu kategoriler arasında en çok metaforu zorlanma kategorisinde kullanmışlardır. Bu durum, TEOG sınavının ortaokul öğrencilerinde stres ve korkuya neden olduğunu ortaya çıkarmakta ve öğrencilerin TEOG sınavı nedeniyle sınav kaygısı yaşadıklarını göstermektedir. Uygulanan eğitim sisteminde sınavların yerinin artması ve öğrenci üzerinde artan baskı nedeniyle son yıllarda sınav kaygısının yaygınlığı artmıştır. Birçok öğrenci sınavın anlamını, notla değerlendirilmek, kendisi hakkında hüküm verilmek, sınıf arkadaşları ile karşılaştırılmak ve sınavın ailesi ve öğretmenleri tarafından muhtemel olumsuz sonucunun kötü karşılanacağı şeklinde 
algılamaktadır (Mayer, 2008, s.1). Bu bağlamda yapılan araştırmalarda sınav kaygısı yaygınlık oranının temel eğitimde \%18 olduğu görülürken orta öğretimde \%40'lara ulaştığı görülmektedir. Bu durum sınav kaygısı yaygınlığının eğitim basamakları ilerledikçe arttığını göstermektedir. Dolayısıyla ilerleyen eğitim aşamalarında sınav kaygısının yaygınlık oranının artması beklenmektedir (McDonald, 2001, akt; İzgi ve Gücüm, 2012). Bu ifade, öğrencilerin TEOG sınavı nedeniyle yaşadıkları stres ve kaygıyı destekler niteliktedir.

Araştırmaya katılan köyde öğrenim gören öğrencilerin TEOG sınav1 için ürettikleri metaforlar, ilçe ve il merkezinde öğrenim gören öğrencilere göre farklılık göstermektedir.

Köy öğrencileri TEOG sınavına yönelik daha çok önem (30) ve hedef (25) kategorilerinde metafor üretmişlerdir. Bu durum TEOG sınavının köyde öğrenim gören öğrenciler için önemli olduğu ve ortaöğretim kurumlarında daha iyi bir eğitim görme ve iyi bir gelecek sağlama adına bir araç veya aşama olarak görüldüğü sonucunu ortaya çıkarmaktadır. Ocak, Akgül ve Y1ldı'ın (2010),

"Gelecekte iyi bir hayat plânlayanlar, bunun iyi bir meslekle elde edilebileceğinin, iyi bir mesleğinde, iyi bir üniversiteyi kazanmakla olacağının farkindadırlar dolayısıyla tüm bunlara ulaşabilmenin yolu, ayn zamanda kaliteli bir ortaöğretim kurumunu kazanmakla başlamaktadir, uygulanmakta olan ortaögretime geçiş sistemlerinde, öğrenci için çok önemli olan bu hedeflerin yolu, iki üç saatlik sinav sürecinden geçmektedir."

şeklindeki ifadesi, köyde öğrenim gören öğrencilerin TEOG sınavına ilişkin bakış açılarını destekler niteliktedir.

İlçede öğrenim gören öğrenciler TEOG sınavına ilişkin daha çok zorlanma (25) ve hedef (22) kategorisinde metafor üretmişlerdir. Bu durum öğrencilerin TEOG sınavı nedeniyle stres, korku ve sınav kaygısı yaşadıklarını, aynı zamanda TEOG sınavını daha iyi bir lise dolayısıyla daha iyi bir gelecek için araç olarak gördükleri sonucuna ulaştırmaktadır. Kaygı, insan olmanın ve hayatın normal işleyişinde olumlu yönü de olan bir durumdur. Yaşama coşkusuna sâhip olmaya, hayallerin peşinden koşmaya, zihinsel olarak uyanık olmaya ve hedeflere ulaşmaya yardımcı olan itici bir güçtür (Mayer, 2008, s.2). Küçük'e (2010) göre sınav kaygısı, bireyin öğrenim ha- 
yatı boyunca birçok kez yaşadığı duygu durumudur. Bu durum, sınava yeteri kadar hazırlanılmaması, verimli çalışma yöntemlerinin bilinmemesi, başarı beklentisinin sâhip olunan yeterlik düzeyinin üzerinde olması, geçmişte yaşanan kötü sınav deneyimleri, özgüven eksikliği gibi birçok nedenle sınav öncesinde ve sınav sırasında performans göstermesi beklenen kişide görülen endişe ve huzursuzluk olarak tanımlanmaktadır. Bu ifade ilçede öğrenim gören öğrencilerin TEOG sınavına ilişkin bakış açılarını destekler niteliktedir.

İl merkezinde öğrenim gören öğrencilerin TEOG sınavına ilişkin zorlanma (23) ve beklenti (21) kategorisinde metafor üretmeleri, bu öğrencilerin TEOG sınavı nedeniyle stres ve sınav kaygısı yaşadıkları, aynı zamanda da sınav sonucu adına ümitli olduklarını göstermektedir. Baltaş ve Baltaş (akt; Alyaprak, 2006), sinav kaygisı ile daha az rahatsız edici bir duygu olan ve kişiyi güdüleyen sınav korkusunu birbirinden ayırmışlardır. Bu araştırmacılara göre, sınavdan korkan bir öğrenci, yaklaşan sınava göre zamanını ayarlamaya çalışmakta ve zamanla korkusu azalmaktadır. Şüphesiz, öğrenci s1navdan önce bir heyecan duymaktadır; ancak bu heyecan, onu başarıya götürecek, canlı tutacak ölçüde gerekli bir duygudur. Bu ifade il merkezi öğrencileri için elde edilen sonucu destekler niteliktedir.

Ayrıca bu araştırma, köyde öğrenim gören öğrencilerin, ilçe ve il merkezinde öğrenim gören öğrencilere göre daha az stres, korku ve sinav kaygısı yaşadıklarını göstermektedir. Benzer sınav uygulamaları dünyanın birçok ülkesinde uygulanmaktadır. Bunlardan birisi Asya ülkesi olan Avustralya'da uygulanan sinav sistemidir. 3., 5., 7. veya 9. sinıfta okuyan her Avustralya öğrencisinin mayıs ayında katıldığ ve temel öğrenim alanları olan okuma-yazma ve matematik becerilerinde yapılan bu testlere NAPLAN denilmektedir. Çocukların okuma-yazma ve matematik becerilerinin okul, eyalet ve ulus seviyesinde anlaşılmasına olanak verir. Anne-babaların, çocuklarının Avustralya genelindeki akranlarına kıyasla durumlarını anlamalarına yardım eder. NAPLAN sınavları, sonuçlara bağlı olarak herhangi bir ödül veya ceza ile değerlendirilmemektedir. NAPLAN testler öğrencilerin sınıf geçme veya kalmalarını etkilemez (NAPLAN, 2016). Thompson (2012) tarafından NAPLAN testlerin etkilerini belirlemeye yönelik Batı ve Güney Avustralya'daki devlet okullarında, Katolik okullarında ve özel okullarda çalışan 961 öğretmenin görüşlerini belirlemeye yönelik bir araştırma yapıl- 
mıştır. Araştırmada, öğretmenlerin \%51'i NAPLAN testlerin öğrencilerde strese neden olduğunu ve öğrenciler üzerinde olumsuz bir etki oluşturduğunu bildirmiştir (Howell, 2012).

Kayapınar (2006), Ortaöğretim Kurumları Öğrenci Seçme ve Yerleştirme Sınavına hazırlanan ilköğretim 8. sınıf öğrencilerinin bazı değişkenlere göre sınav kaygılarını incelemiştir. Araştırmada 20 maddeden oluşan "Sınav Kaygısı Envanteri" ve 27 maddeden oluşan bir "Kişisel Bilgi Formu" kullanılmıştır. Araştırmanın örneklemi Afyonkarahisar ilinde dershanelere giden 632 ilköğretim 8. sınıf öğrencisinden oluşmaktadır. Araştırmanın sonucunda, cinsiyet, yaş, anne-baba öğrenim durumu, dershaneye devam süresi, aylık gelir, test alanı, anne-baba tutumu, çalışma programı, anne-baba mesleği, ailenin ve öğrencinin başarı beklentisi, spor faaliyetleri, "Orta Öğretim Sınav1" puan/alan türü, öğrencinin ortaöğretim hedefi, ailenin sınav başarısı tutumu grupları arasında sınav kaygısı açısından anlamlı bir fark belirlenmiştir.

Ülkemizdeki sınav uygulamasına benzer bir uygulama da diğer bir Asya ülkesi olan Singapur'da uygulanmaktadır. Singapur'da ilkokul eğitimi 6 yıl sürmektedir ve 7-12 yaş arasında zorunludur. Eğer aileler çocuklarını okula kaydettirmezlerse zorunlu eğitim yasasına göre suç işlemiş olmaktadırlar. İlkokul bitirme sınavı (PSLE), ortaokula başlamadan önce, 6. sınıfa geçecek bütün öğrencilerin girmek zorunda olduğu ulusal bir sınavdır. Bu sınav Millî Eğitim Bakanlığı tarafından uygulanmaktadır. Ülke genelinde uygulanmakta olan bu sınav dört dersten yapılmaktadır. Bunlar; İngilizce, ikinci yabanci dil, Matematik ve Fen dersleridir. Bu sinavda elde edilen sonuçlar hem bireysel öğrenci bazında hem de diğer öğrencilerle karşılaştırılarak bir sıralama oluşturulmaktadır. Bu durum sınavın çok kolay ve çok zor sorular içermesini gerektirmektedir. Bu sınav neticesinde öğrenciler siralamalarına göre ilkokul sonrası çeşitli akademik kurumlara yönlendirilmektedirler (Subramaniam, Verma, Cheok, Lee, Wong ve Chong, 2012, s.138).

Birleşik Devletlerde Jones ve arkadaşları (1999), Kuzey Carolina'da 16 farklı ilkokulda görev yapan 236 sertifikalı öğretmenin algılarını belirlemeye yönelik bir araştırma yapmışlardır. Araştırma Halk Eğitimin Yeni $A B C$ 'si programı dâhilinde uygulanan High-Stakes testleri hakkındadır. Buna göre, öğretmenlerin \%28'si bu süreçte öğrencilerinin öğrenmeye hazır olduğunu, \%15'i ögrencilerinin kendine güven duyduğunu, \%61'i öğrencile- 
rinin yüksek kaygı yaşadığını ve \%48.5'i de bu programın öğrencilerinin öğrenme istekleri üzerinde olumsuz etki gösterdiğini bildirmiştir (Jones ve ark., 1999, s.201).

$\mathrm{Bu}$ durum, sınav kaygısının hem ülkemizde hem de bütün dünyada öğrencilerin ortak problemi olduğunu göstermektedir.

$\mathrm{Bu}$ araştırma TEOG sınavına yönelik yapılmış metaforik ilk araştırmadır. Öğrencilerin TEOG sınavına ilişkin duygu ve düşüncelerinin farklı yöntemlerle de incelenebileceği daha kapsamlı bir araştırma yapılabilir. 8 . sınıfta öğrencisi bulunan velilerin TEOG sınavına yönelik metaforik algıları belirlenebilir. Ayrıca köyde öğrenim gören öğrencilerde stres ve sınav kaygısının daha düşük olmasının nedenleri araştırılabilir.

\section{Kaynakça}

Alyaprak, İ. (2006). Üniversite sinavina hazırlanan öğrencilerde sinav kaygısını etkileyen faktörlerin incelenmesi. Yayımlanmamış Yüksek Lisans Tezi, Ege Üniversitesi Sosyal Bilimler Enstitüsü.

Birinci, D. K. (2014). Merkezi sistem ortak sınavlarında ilk deneyim: Matematik dersi. Ĕgitim ve Öğretim Araş̧tırmaları Dergisi, 3(2), 8-16.

Çelik, Z. (2011). Ortaöğretime geçiş sistemi ve meşruiyet kaynakları. M. Orçan, (Ed.), 21. yüzyılda Türkiye'nin eğitim ve bilim politikaları sетроzуити içinde (53-61). Ankara: Eğitim-Bir-Sen.

Çepni, S., Özsevgeç, T. ve Gökdere, M. (2003). Bilişsel gelişim ve formal operasyon dönem özelliklerine göre ÖSS fizik ve lise fizik sorularının incelenmesi. Milli Eğitim Dergisi, 157, 30-39.

Çepni, S. ve Çil, E. (2010). Yeni fen ve teknoloji programları (4-8): Planlama, uygulama ve SBS ile ilişskilendirme. Ankara: PegemA Yayıncılık.

Demirel, Ö. (2006). Öğretimde planlama ve değerlendirme öğretme sanatı. Ankara: Pegem Yayınc1lı.

Güveli, E., İpek A. S., Atasoy E. ve Güveli, H. (2011). Sınıf öğretmeni adaylarının matematik kavramına yönelik metafor algıları. Turkish Journal of Computer and Mathematics Education, 2(2), 140-159. 
Howell, A. (2012, Aral1k). The silent voice in the NAPLAN debate. Exploring children's lived experiences of the tests. Uluslararas1 AARE APERA konferansinda sunulan bildiri, Sydney, Avustralya.

İlter, İ. (2015). Primary school teacher candidates' metaphorical perceptions related to multigrade classes concept. Elementary Education Online, 14(4), 1450-1468.

İnanç, B., Y. ve Hanımoğlu, E. (2011). Seviye belirleme sınavına girecek olan ilköğretim ikinci kademe öğrencilerinde sınav kaygıs1, mükemmeliyetçilik ve anne-baba tutumu arasındaki ilişkinin incelenmesi. Ç.Ü. Sosyal Bilimler Enstitüsü Dergisi, 20(1), 351-366.

İzgi, Ü. ve Gücüm, B. (2012). Fen eğitiminde portfolyo değerlendirme kullanımının sınav kaygısı ve öğrenmenin kalıcılığı üzerine etkisi. Ĕ̈itim ve Bilim, 37(164), 71-79.

Jones, M. G., Jones, B. D., Hardin, B., Chapman, L., Yarbrough, T. ve Davis, M. (1999). Impact of high-stakes testing on teachers and students in North Carolina. Phi Delta Kappan, 81, 199-203.

Kaşıkçı, Y. (2015). İkinci dönem TEOG sınavı fen ve teknoloji sorularının bazı kriterlere göre değerlendirilmesi. Eğitim ve Öğretim Araştırmaları Dergisi, 4(1), 225-232.

Kaşıkçı, Y., Bolat, A., Değirmenci, S. ve Karamustafaoğlu, S. (2015). İkinci dönem TEOG sınavı fen ve teknoloji sorularının bazı kriterlere göre değerlendirilmesi. Eğitim ve Öğretim Araştırmaları Dergisi, 4(1), 225-232.

Kayapınar, E. (2006). Ortaöğretim kurumları öğrenci seçme ve yerleştirme sinavı (OKS)'na hazırlanan ilköğretim 8. sinıf öğrencilerinin kayg düzeylerinin incelenmesi (Afyonkarahisar ili örneği). Yayımlanmamış yüksek lisans tezi, Kocatepe Üniversitesi Sosyal Bilimler Enstitüsü.

Koğar, E., Y. ve Aygün, B. (2015). Temel eğitimden orta öğretime geçiş sınavı (TEOG)'nın matematik temel alanına ait testlerin kapsam geçerliğinin incelenmesi. Pegem Ĕ̈itim ve Öğretim Dergisi, 5(5), 667-680. 
Koç, N. (2007). Öğretim sürecinde ölçme ve değerlendirme: Temel ilkeler. İlköğretmen Eğitimci Dergisi, 8, 23-27.

Kutlu, Ö. ve Karakaya, İ. (2007). Ortaöğretim kurumları öğrenci seçme ve yerleştirme sınavında kullanılan testlerin faktör yapılarının belirlenmesine ilişkin bir araştırma örneği. İlköğretim Online Dergisi, 6(3), 397-410, http://ilkogretim-online.org.tr.

Küçük, P. D. (2010). Müzik öğretmeni adaylarının sınav kaygısı, benlik saygısı ve çalgı başarıları arasındaki ilişkinin incelenmesi. Ahi Evran Üniversitesi Eğitim Fakültesi Dergisi, 11(3), 37-50.

Mayer, D. P. (2008). Overcoming school anxiety: How to help your child deal with separation, tests, homework, bullies, math phobia, and other worries. American Management Association: New York.

MEB. (1998). Ortaöğretim kurumları ögrenci seçme ve yerleştirme sinavı kılavuzu (OKS). Ankara: Türk Tarih Kurumu Basımevi.

MEB. (2003). Ortaöğretim kurumları öğrenci seçme ve yerleştirme sinavı kılavuzu (OKS) ve özel okullar sınavı (ÖOS) tanitım kitapçı̆̆ı. Ankara: Eğitim Teknolojileri Genel Müdürlüğü (EĞİTEK), Ölçme ve Değerlendirme Dairesi Başkanlığı.

MEB. (2005). Orta öğretim kurumlarına öğrenci seçme sınavı başvuru for$\mathrm{mu}$.

http://yegitek.meb.gov.tr/Sinavlar/Klavuz/2005/2005OKSekilavuz.pdf.

MEB. (2008). 64 soruda ortaögretime geçiş sistemi ve seviye belirleme sınavı örnek sorular. Eğitimi Araştırma Geliştirme Dairesi (EARGED), Ankara: MEB yayınları.

MEB. (2013). 2013-2014 eğitim-öğretim y1lı orta öğretime geçiş ortak sinavlar1 e-Kilavuzu.

http://www.meb.gov.tr/sinavlar/Dokumanlar/2013/kilavuz/2013_OGE S_Klvz.pdf.

Miles, M. B. and Huberman, A. M. (1994). Qualitative data analysis: an expanded sourcebook. (2. bask1). Calif.: SAGE Publications. 
NAPLAN. (2014).

http://www.vcaa.vic.edu.au/Documents/naplan/parentreport/turkish-na planparentinfo.pdf.

Ocak, G., Akgül, A. ve Yıldız, S. Ş. (2010). İlköğretim öğrencilerinin ortaöğretime geçiş sistemine (OGES) yönelik görüşleri (Afyonkarahisar Örneği). Ahi Evran Üniversitesi Eğitim Fakültesi Dergisi, 11(1), 37-55.

Ocak, G. ve Gündüz, M. (2006). Eğitim fakültesini yeni kazanan öğretmen adaylarının öğretmenlik mesleğine giriş dersini almadan önce ve aldıktan sonra öğretmenlik mesleği hakkındaki metaforlarının karşılaştırılması. Afyon Kocatepe Üniversitesi Sosyal Bilimler Dergisi, 8(2), 293-309.

Oğuz, A. (2005). Öğretmen eğitim programlarında metafor kullanma. H. Kıran, (Ed.), XIV. Ulusal Ĕgitim Bilimleri Kongresi. Pamukkale Üniversitesi, Eğitim Fakültesi, Denizli, 582-588.

Patton, M. Q. (2002). Qualitative evaluation and research methods (3. bask1). Thousand Oaks, CA: Sage Publications, Inc.

Subramaniam, M., Verma, S., Cheok, C., Lee, I., Wong, J. ve Chong, S., A. (2012). Prevalence and correlates of psychotic symptoms among Asian males. Soc Psychiatry Psychiatr Epidemiol, 47, 137-144.

Sarıer, Y. (2010). Ortaöğretime giriş sınavları (OKS-SBS) ve PISA sonuçları 1şı̆̆ında eğitimde fırsat eşitliğinin değerlendirilmesi. Ahi Evran Üniversitesi Eğitim Fakültesi Dergisi, 11(3), 107-129.

Semerci, Ç. (2007). Eğitimde ölçme ve değerlendirme. E. Karip, (Ed.), Ölçme ve değerlendirme içinde (1-15). Ankara: PegemA Yayınları.

Senemoğlu, N. (2005). Gelişim öğrenme ve ögretim kuramdan uygulamaya. Ankara: Gazi Kitabevi.

Şahin, B. (2013). Öğretmen adaylarının matematik öğretmeni, matematik ve matematik dersi kavramlarına ilişkin sahip oldukları metaforik algılar. Mersin Üniversitesi Eğitim Fakültesi Dergisi, 9(1), 313-321. 
Thompson, G. (2012). Effects of NAPLAN: Executive summary. Western Australia: Murdoch University.

Yıldırım, A. ve Şimşek, H. (2011). Sosyal bilimlerde araştırma yöntemleri. Ankara: Seçkin Yayınları. 